\title{
THE IMPACT OF CASH DIVIDENDS AND FIRM FACTORS ON EARNINGS MANAGEMENT - EMPIRICAL EVIDENCE FROM BAHRAIN
}

\author{
Abdelmohsen M. Desoky \\ South Valley University, Egypt \\ University of Bahrain, Bahrain
}




\title{
THE IMPACT OF CASH DIVIDENDS AND FIRM FACTORS ON EARNINGS MANAGEMENT - EMPIRICAL EVIDENCE FROM BAHRAIN
}

\author{
Abdelmohsen M. Desoky \\ South Valley University, Egypt \\ University of Bahrain, Bahrain
}

\begin{abstract}
The main aim of this study is to investigate the impact of cash dividends and firm factors on earnings management. The Ordinary Least Square (OLS) regression analysis is utilized to examine the impact of both cash dividends and firm factors, as independent variables, on earning management, the dependent variable, measured by Jones Model with a cross sectional approach using 27 firms listed in the Bahrain Bourse (BHB) for a period of 10 years starting from 2004 to 2013. Results of the study indicate that cash dividends have no clear impact on earnings management. However, a number of firm factors namely firm ownership structure; firm size; firm financial leverage; firm performance and quality of audit firm have statistically significant impact on earnings management.
\end{abstract}

Keywords: The Bahrain Bourse (BHB), Earnings Management, Cash Dividends, Firm factors.

Abdelmohsen M. Desoky, Associate Professor of Accounting, Faculty of Commerce, South Valley University, Egypt. Currently: Head of Accounting Department, College of Business Administration, University of Bahrain, P.O. Box 32038, Kingdom of Bahrain. E-mail: adesoky@uob.edu.bh 


\section{1- INTRODUCTION}

In general, earnings may be considered as the most significant figure in financial reports. It is believed that they can influence the company's survival. Thus, the issue of earnings management (EM) is of interest not only by academic researchers but also public interest, especially, after the rising number of accounting scandals and financial crisis around the world. It is argued that EM has a strong effect on the accuracy and integrity of financial reports (Healy and Wahlen, 1999). The accounting literature in the EM area has documented that firms manipulate earnings in an upward direction to overcome the problem of declining profits (Graham et al., 2005). In Egypt, Mousa (2011) concluded that Egyptian listed firms exercise EM to raise their reported income. Thus, it is likely that firms may practice EM toward the anticipated dividends (i.e., the previous year's dividends). Lintner (1956) concluded that dividends might play an important role in determining both the current distributions of earnings and retained earnings. Further, Kim et al. (2012) argued that firms have conducted EM to overcome earnings decline potentially captures firms' propensity to manage earnings or to sustain firms' dividend levels.

It was concluded that firms with a high rate of growth might pay dividends to shareholders less than profitable firms with a low rate of growth (Fama and French, 2001). Brav et al. (2005) argued that firms try to smooth yearly dividend trends and continue with the old dividend levels. Firms manipulate their earnings upwards to achieve the planned dividends when earnings are less than last year(s) dividend (Daniel et al., 2008). Dividends may have an impact on manipulating earnings whether higher or lower (Liu, 2011).

The Kingdom of Bahrain (henceforth Bahrain), the interest of the current investigation, is a member of the Gulf Co-operation Council (GCC). According to Law No. 60 for 
the year 2010, Bahrain Bourse (BHB) is a shareholding company. Officially, BHB conducted its operations in June 1989. Seeking for the achievement of a high level of transparency and understanding for all investors around the World, Bahrain issued and activated its Corporate Governance Code (CGC) in 2011. This study might help to enhance the accounting literature on an important area of research, the impact of dividends on EM, through different trends. It tries to explore the association between cash dividends and EM within Bahrain as one of the emerging capital markets and a different socio-economic model. Furthermore, the current study examines a number of firm factors affecting EM, namely firm ownership structure; firm size; firm financial leverage; firm performance and the quality of audit firms. Although a large number of studies on the area of EM have been conducted in developed and developing countries, to the best of the researcher's knowledge, relatively little is known about this area in Bahrain. Besides, the empirical findings of the current study may be fruitful for various parties such as investors and regulators. Lastly, this study may benefit in studying other countries in the Middle East in general and GCC area in particular.

This study is structured as follows. Section 2 presents literature review. Section 3 provides the research methodology, sample selection and the measurement of the study's variables. Section 4 devoted to present results of the study. Finally, section 5 presents conclusions, limitations and future research.

\section{2- LITERATURE REVIEW}

The literature review, which helps in formulating the study hypotheses, are presented in two parts; first, cash dividends and EM; second, firm factors and EM. 


\section{2-1 Cash dividends and earnings management}

The relationship between dividends and earnings has been examined comprehensively. It was reported that firms pay more dividends when earnings ratio to total equity is large, in contrast they will pay less dividends if this ratio drops in the USA (DeAngelo et al., 2006). Kinnunen et al. (2000) concluded that there are significant differences between Finnish firms which issue new shares and other firms which do not do the same in the current period. Such firms use EM to report large earnings. They reported that Finnish firms disclose more earnings in the years of the new issuance of shares over the years that they have no new issuance. Using 37 listed firms on the Helsinki Stock Exchange, Kasanen et al. (1996) examined firms' motivations to manage earnings in Finland during 1970-1989. They found that firms manage earnings to pay out a smooth stream of dividends to their owners.

Previous studies on the relationship between cash dividends and EM provided diversified evidence. For instance, Liu (2011) investigated the relationship between smoothing dividend streams and dividend pay-out ratios in EM using all firms included in Compustat database from 1992 to 2009. Liu (2011) suggested that firms manipulate earnings (upward and downward) through a number of actions to smooth dividend streams and dividend pay-out ratios. Using 320 listed firms on Karachi Stock Exchange during the period 2001 to 2006, Ahmed et al. (2009) reported that the decision about dividend payments is based on the both level of current earnings and the amount of previous dividends. Also, it was reported that other firm characteristics such as financial leverage and investment opportunity have negative impact on dividends while liquidity and ownership concentration are positive.

Using a sample of S\&P 1500 firms from 1992 to 2005, Daniel et al. (2008) reported that earnings are linked with dividend levels and firms may manage earnings upward 
when they expect an earnings drop; consequently dividend payments will be affected. Ling et al (2008) documented a negative relation between dividends and earnings for 100 listed firms in Malaysia from 2002 to 2005. On the other hand, other studies (Healy and Palepu, 1990; Kim et al., 2012) reported that firms cut dividends when reported earnings fall short of past dividends. Haider et al (2012) investigated the association between EM and dividend pay-outs from the period of 2005 to 2009 in Pakistan. They reported a weak relationship between the two variables. Shah et al (2010) test the association between EM and dividends in both Pakistani and Chinese listed firms. They concluded that no relation exists between EM and dividend payout in both countries. In the light of the above discussion, it can be suggested that dividends can be one of the driving forces behind EM. Thus, the following hypothesis (H1) can be formulated:

H1: There is a significant relationship between cash dividends and EM.

\section{2-2 Firm factors and earnings management}

A variety of firm factors influencing EM were examined in the literature (such as firm size; foreign listing; audit quality; type of industries; profitability; ownership structure; corporate governance characteristics; and others). For example, Hutchinson and Leung (2007) argued that many organizational characteristics are the main factors affecting the decision to manipulate earnings, although they may provide opportunities and incentives for such manipulation. Because of the number of Bahraini firms that have issued new securities and listed in a foreign stock market is very limited, the two variables were excluded in the current study. With this in mind, this study has selected a number of the above characteristics namely firm ownership structure; firm size; firm financial leverage; firm performance; quality of audit firm) as independent variables. Relevant literature on these factors is presented below to assistance in developing hypotheses of the study. 


\section{2-2-1 Firm ownership structure}

Ownership structure of a firm plays a significant oversight role where it can reduce the occurrence of earnings manipulation (Alves, 2012). Existing literature showed that firm ownership structure is associated with EM. Moreover, the literature addressed different classes of ownership structure including large block-holders; managerial; institutional; family; foreign ownerships can have different incentives for EM. For instance, Alves (2012) investigated the impact of ownership structure on EM by studying the behaviour of 34 listed Portuguese firms in the period from 2002 to 2007. A firm ownership structure was classified into three categories as managerial, concentration and institutional ownerships. Alves (2012) reported that the first two categories have a significant negative relationship with EM, which suggests that reducing the levels of EM can improve the level of the quality of annual earnings. In contrast, the third category, institutional ownership is insignificant.

In this study, two types of ownership structure were used, institutional ownership and block-holder ownership (10\% or more) because they have the largest percentage of ownership in the capital market thus they can affect the financial markets. According to agency theory, institutional ownership can be considered as a useful tool of governance mechanism (Alves, 2012, p.61). Institutional investors can have control over management activities, while it is difficult for small business to do so. In this regard, many studies concluded that institutional ownership can reduce the opportunity of managers in manipulating earnings (e.g.: Cornett et al. 2008; Koh 2003). Chung et al., (2002) documented that an increase in the percentage of institutional ownership obstructed managers from increasing or decreasing reported earnings. In the same line, Koh (2003) found a positive association between EM and a low level of institutional ownership. 
Conversely, a negative association has been reported by Ben-Naser et al. (2009) who conducted a study on 174 firms from 29 countries from 1980 to 2003. Siregar and Utama (2008) found that in both types of ownerships, both large family ownership and non-business firms might engage in EM actions more than other types of firms; while institutional ownership has no significant impact on EM. AlFayoumi et al. (2010) used a sample of Jordanian industrial firms, to verify the effect of ownership structure on EM. They classified ownerships into three types: insiders, institutions and block-holders. They reported non-significant relationship between institutions and block-holders and EM.

Moreover, other studies suggested that large blockholders could help in reducing EM activities if they play a supervisory role. Consequently, financial reporting can be enhanced (Dechow et al., 1996; Jensen and Meckling, 1976). Zhong et al. (2007) examine the behaviour and impact of outside block-holder ownership on EM by US firms. They concluded that outside block-holder ownership has a positive relationship with EM in firms with low level of earnings. Similar results were reported by Choi et al. (2004). Based on the above discussion, the relationship between EM and firm ownership structure have diversified results, consequently, the following hypotheses can be formed as follows:

$\mathrm{H} 2$ a: There is a significant relationship between institutional ownership and EM.

$\mathrm{H} 2 \mathrm{~b}$ : There is a significant relationship between blockholders and EM.

\section{2-2-2 Firm size}

Size of a firm plays an active role in determining the behavior of the firm. While large firms do not manipulate earnings to avoid losses, small firms often manipulate earnings to avoid losses (Lee and Choi, 2002). Large firms are more politically sensitive than small ones and experience higher political costs if they manage earnings (Warfield et 
al., 1995). Kim et al (2003) investigated the relationship between EM and firm size (small, medium and large) using a sample over 18 years. They found that firm size had a strong impact on EM, where larger size firms are more involved in EM as compared to smaller firms.

In the USA, Jones (1991) argued that large firms are vulnerable to criticism by pressure groups in the communities. They are also subject to analysts and institutional investor scrutiny therefore, they may reduce earnings as they become publicly traded. In the same line, other studies documented that big sized firms tend to smooth or reduce earnings more than small ones (Moses, 1987). In Egypt, Mousa (2011) reported that, in three sectors (food, healthcare and services sector), firm size is one of the most influencing factors on EM. However, Othman and Zeghal (2006) reported that firm size has an effect on EM magnitude within Canadian and French firms. Further, Chung et al. (2005) reported that firm size has a significant positive relationship with EM. On the other hand, Siregar and Utama (2008) found in Indonesia inconsistent evidence that firm size has a significant influence on EM using a sample of 144 firms. In the current study, natural logarithm of total assets at the end of the year was used as a proxy of firm size (FSIZE). Based on the previous discussion, the third hypothesis is developed as:

H3: There is a significant relationship between firm size and EM.

\section{2-2-3 Firm financial leverage}

Financial leverage indicates to the firm use of the various finance resources to fund its operations and achieve growth which may result an increase its return on equity (ROE). In general, Agency theory suggests a strong link between financial leverage and disclosure (Jensen and Meckling, 1976). Firms use financial leverage as a way to enhance firm's values and consequently reduce the cost of funding (Naz et al. 2011). According to Watts and Zimmerman 
(1990) firms with a large percentage of financial leverage tend to manipulate earnings by shifting them from the future to the current period. Banking and finance corporations rely heavily on the financial reports of firms requesting loans (Yoon and Miller, 2002). Firms in need for loans from banks and/or finance corporations are motivated to increase reported income and accruals and to support the level of profitability of the firm and then obtain low cost financing (DeFond and Jiambalvo, 1994). Naz et al. (2011) reported a significant negative relationship between financial leverage and EM by using 75 firms from Cement, Sugar and Chemical sectors in Pakistan during the period from 2006 to 2010.

Coulombe and Tondeur (2001) concluded that managers in French firms with a large percentage of debts are unlikely to practice EM in an attempt to impact on investor perceptions. Conversely, Othman and Zeghal (2006) provide evidence that financial leverage has no significant relationship with EM for Canadian firms, while in French firms financial leverage does contribute to manage earnings upwards. Debt/asset ratio is used as a proxy for financial leverage in the current study. In the light of the above arguments, it is possible to hypothesize that:

H4: There is a significant relationship between firm financial leverage and EM.

\section{2-2-4 Firm performance}

The literature provides evidence on the relationship between firm performance and EM. For instance, in Korea, Yoon and Miller (2002) found evidence that Korean manufacturers are used to manipulate earnings based on their operational performance. When these firms have a negative operating performance they adopt policies to increase income while in very special cases they may use policies to reduce income. Further empirical evidence was provided from Singapore and Thailand by Charoenwong and Jiraporn (2009) who 
investigated whether EM behaviours existed in listed firms in both countries from 1975 to 2003. They stated that only Thai firms (financial and non-financial) have managed their earnings to avoid reporting losses and negative earnings growth. McNichols (2000) reported a significant positive association between firm performance measured by return on assets (ROA) and discretionary accrual estimates.

In the same way, Chung et al. (2005) reported that firms with a high free cash flow adopt an income-increasing discretionary accruals policy to overcome problems related to investments and different expenditures. The empirical results showed a positive relationship between free cash flow and discretionary accruals. In the current study, firm performance was measured by ROA. In the light of the previous discussion, the fifth hypothesis can be suggested as:

H5: There is a significant relationship between firm performance and EM.

\section{2-2-5 Quality of audit firms}

Conflicting results were revealed on the impact of quality of audit firms on EM practices. A number of studies (e.g.: Chung et al., 2005; Krishnan, 2003; Rajgopal et al., 2002) pointed out a negative relationship between the amount of discretionary accruals and the quality of audit firms. Discretionary accruals are low with big audit firms and high with small audit firms. In contrast, Othman and Zeghal (2006) found evidence that auditors have no substantial influence on the magnitude of EM within both French and Canadian firms. Similar result was reported in Indonesia by Siregar and Utama (2008). Studies on the influence of quality of audit firms on EM have mixed results; therefore the sixth hypothesis is suggested as.

H6: There is significant relationship between the quality of audit firms and EM. 


\section{3- RESEARCH METHODOLOGY}

\section{3-1 Empirical data}

Data needed for this investigation were gathered from 27 Bahraini non-financial and trading firms listed on the BHB in a period of 10-year (2004-2013). The total number of yearly firm observations is 270 . These firms cover nearly $58 \%$ of the total market capitalization of all listed firms in BHB (by end of 2013). All financial firms and firms without sufficient data were excluded from the sample. The present study has used a number of related web sites such as (www.bahrainbourse.net, www.mistnews.com; www.gulfbase.com; and www.mubasher.net) to collect data of the dependent and independent variables of this study. Web pages of each firm included in the sample were visited for the same purpose.

\section{3-2 Definition of study's variables}

Since the objective of the present study is to examine the impact of cash dividends and firm characteristics on EM, the absolute value of discretionary accruals is used in the current study as a proxy EM. The most widely used method to measure EM in the accounting literature is the Jones (1991) model.

\section{3-2-1 Estimation of discretionary accruals (the dependent variable)}

Measuring of management's discretion over earnings is the corner stone in EM studies. The literature has provided different approaches to measure EM (McNichols, 2000). However, it presents an excess of using of the aggregate accruals approach to recognise discretionary behaviour (Yoon and Miller, 2002; Othman and Zeghal; 2006; Caramanis and Lennox; 2008; Mousa, 2011). Jones (1991) proposed a model to specify a linear association between total accruals and change in sales, property, plant and equipment and to fix the effect of nondiscretionary factors 
on accruals. Jones (1991, p.207) defines total accruals as "the difference between earnings and operating cash flow". The main idea is that information on operational cash flow is a more objective measure of performance than earnings. Following the existing literature (Coles et al., 2006; Othman and Zeghal; 2006; Caramanis and Lennox; 2008), the current study used the Jones model ${ }^{1}$ (1991) to estimate discretionary accruals as the proxy of EM. Following Hribar and Collins (2002) and Othman and Zeghal (2006), earnings is defined as "net income before extraordinary items and cash flows from operation (CFO) is net cash flows from operating activities reported in the statement of cash flows". Then, total accruals have been computed as the difference between earnings and CFO. In the current investigation, 27 firms listed in BHB (with total observations of 270) were used. The Jones model (1991) relates total accruals to the change in revenue $(\triangle \mathrm{REV})$ and the level of gross property, plant and equipment (PPE). First, Jones model components are estimated as follows:

$T_{A C C} i j, t=a 0 j+a 1 j \triangle R E V_{i j, t}+a 2 j P P E G_{i j, t}+e_{i j, t}($ all these variables in the model are deflated by lagged total assets) as follows:

$\operatorname{TACC}_{i j, t} / \operatorname{TASS}_{i j, t-1}=\operatorname{aOj}\left(1 / \operatorname{TASS}_{i j, t-1}\right)+\operatorname{alj}\left(\Delta R E V_{i j, t} /\right.$ TASS $_{i j, t-1}+a 2 j$ PPEG $i j, t / T_{1}$ TASS $\left.i j, t-1\right)+e i j, t$ Eq. (1)

TACC $_{i j, t}$ is the total accruals for firm $i$ in industry $\mathrm{j}$ in year $\mathrm{t}$, calculated by net income before extraordinary items minus cash flow from operations; TASS $_{\mathrm{ij}, \mathrm{t}-1}$ is total assets for firm $\mathrm{i}$

\footnotetext{
1 For more details on Jones model, see Coles et al. (2006) who present a unique discussion on the measurement of discretionary accruals. In addition, other studies such as Dechow et al. (1995) and Coles et al. (2006) provide a critical analysis for Jones model, to identify advantages and disadvantages for this model, at the same time, suggest some modifications.
} 
in industry $\mathrm{j}$ in previous year $\mathrm{t}-1 ; \Delta \mathrm{REV}_{\mathrm{ij}, \mathrm{t}}$ is the change in revenues for firm $\mathrm{i}$ in industry $\mathrm{j}$ between year $\mathrm{t}-1$ and $\mathrm{t}$; PPEG $_{\mathrm{ij}, \mathrm{t}}$ is gross property, plant, and equipment for firm $\mathrm{i}$ in industry $\mathrm{j}$ in year $\mathrm{t}$. The estimates of $\mathrm{a} 0 \mathrm{j}$, $\mathrm{a} 1 \mathrm{j}$ and $\mathrm{a} 2 \mathrm{j}$, are those obtained from the Jones model. Secondly, using the estimated coefficients ( $\hat{a} \mathrm{j}$, $\hat{a} 1 \mathrm{j}$ and $\hat{a} \mathrm{j}$ ) from regression (Eq. 1), the non-discretionary (NDACC $\mathrm{ij,t}$ ) component of total accruals have been evaluated for firm $i$ in industry $j$ in year $\mathrm{t}$ observation as follows:

$N D A C C_{i j, t}=$ TACC $_{i j, t} / \operatorname{TASS}_{i j, t-1}=\hat{a} O j\left(1 / \operatorname{TASS}_{i j, t-1}\right)+\hat{a}$

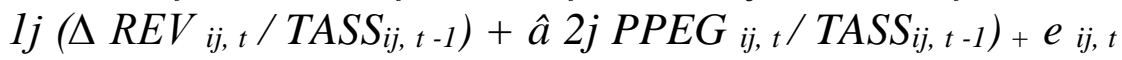
Eq. (2)

The proxy for $\left(\mathrm{DACC}_{\mathrm{ij}, \mathrm{t}}\right.$ (for firm $\mathrm{i}$ in industry $\mathrm{j}$ in year $\mathrm{t}$ ) is defined as the residuals. DACC $\mathrm{ij}_{\mathrm{j}, \mathrm{t}}$ is obtained from the extended Jones model by computing the simple equation total accruals minus estimated non-discretionary accruals.

$D A C C_{i j, t}=T_{A C C} i j, t-N D A C C_{i j, t}$

Therefore,

$D A C C_{i j, t}=T_{A C C} i j, t-\hat{a} 0 j\left(1 / T A S S_{i j, t-1}\right)-\hat{a} 1 j\left(\triangle R E V_{i j, t} /\right.$ $\left.\left.T_{A S S} i j, \quad t \quad-1\right) \quad-\quad \hat{a} \quad 2 j \quad P P E G \quad i j, \quad t \quad / \quad T A S S_{i j,} \quad t \quad-1\right)$ Eq. (3)

\section{3-2-2 Independent variables}

In this study, the dependent variable (discretionary accruals oor DACC $\mathrm{C}_{\mathrm{ij}, \mathrm{t}}$ ) is used as a proxy of EM measured by Jones Model (details in Eq. 1, 2 \& 3). Additionally, eight independent variables are selected for cash dividends and firm characteristics. Only one type of dividends which is cash dividends was considered. Two different measures have been used to reflect cash dividends. First, the cash dividend payout ratio (PAOUT) presents the amount of the firm's dividends each year to shareholders divided by its net income. Second, the cash dividend yield ratio (YIELD) refers to the amount of the firm's dividends each year to shareholders divided by its share price. 
Firm characteristics, six variables namely institutional ownership; block-holder ownership; firm size (FSIZE); firm financial leverage (FLEVER); firm performance and quality of audit firms (QAUDT), and their related proxies are presented in Table 1 below.

Table 1: Summary of all the variables in the study

\begin{tabular}{|c|c|}
\hline Variables & Definitions \\
\hline $\begin{array}{l}\text { Dependent Variables } \\
\text { Earnings management }(\mathrm{EM})\end{array}$ & $\begin{array}{l}\text { discretionary accruals } \text { DACC }_{\mathrm{ij}, \mathrm{t}} \text { (measured by Jones } \\
\text { Model Eq. } 1,2 \& 3 \text { ) }\end{array}$ \\
\hline $\begin{array}{l}\text { Independent Variables } \\
\text { Cash dividend payout ratio } \\
\text { (PAOUT) }\end{array}$ & $\begin{array}{l}\text { Cash dividend / the net income excluding minority } \\
\text { interest and extraordinary income. }\end{array}$ \\
\hline $\begin{array}{l}\text { Cash dividend yield ratio } \\
\text { (YIELD) }\end{array}$ & Cash dividend per share/the closing price per share. \\
\hline $\begin{array}{l}\text { Institutional ownership } \\
\text { (INOWO) }\end{array}$ & $\%$ of shares owned by the institutional ownership. \\
\hline $\begin{array}{l}\text { Block- holder ownership } \\
\text { (BKOWN) }\end{array}$ & $\begin{array}{l}\% \text { of shares owned by the block-holder ownership } 10 \% \\
\text { or more. }\end{array}$ \\
\hline Firm Size (FSIZE) & $\begin{array}{l}\text { The natural logarithm of total assets at the end of the } \\
\text { year. }\end{array}$ \\
\hline $\begin{array}{l}\text { Firm financial leverage } \\
\text { (FLEVER) }\end{array}$ & Total liabilities/total assets. \\
\hline Firm performance (ROA) & Net income/total assets. \\
\hline $\begin{array}{l}\text { Quality of audit firms } \\
\text { (QAUDT) }\end{array}$ & $\begin{array}{l}\text { Dummy variable takes one if the firm was audited by } \\
\text { big audit firm and zero otherwise. }\end{array}$ \\
\hline
\end{tabular}

\section{3-2-3 Data analysis}

The study has conducted the Ordinary least square (OLS) regression analysis for the EM, as a dependent variable, and eight independent variables (PAOUT; YIELD; INOWN; BKOWN; FSIZE, FLEVER; ROA and QAUDT) were included in the model.

The regression model of EM was estimated in the current study as follows:

\section{Model 1:}

$\mathrm{Y}(\mathrm{EM})=\beta_{0}+\beta_{1}$ PAOUT $+\beta_{2}$ YIELD $+\beta_{3}$ INOwn + $\beta_{4}$ BKOwn $+\beta 5$ FSIZE $+\beta 6$ FLEVER $+\beta 7$ ROA $+\beta 8$ QAudt $+\varepsilon$

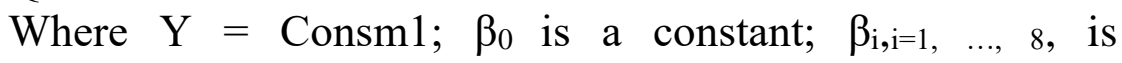
parameters; and $\varepsilon$ is error term. 


\section{4- Empirical results and analysis}

The empirical analysis in this study includes two statistical methods, a descriptive statistics and regression analyses, to test the research hypotheses formulated earlier.

\section{4-1 Descriptive statistics}

As mentioned earlier, discretionary accruals which were used as the proxy of EM are the residual from a regression of total accruals. In line with previous studies (e.g., Dechow and Dichev, 2002; Daniel et al., 2008) table 2 shows that the average EM is negative of (-183.41). The average mean of firms pay dividends (PAOUT) is $25.22 \%$ of the sample firmyears while YIELD is $3.08 \%$ with a standard deviation of $9.20 \%$. The average mean of ROA is $8.14 \%$ with a large standard deviation of $25.84 \%$. Besides, the average mean of FLEVER is $24.45 \%$ with a large standard deviation of 9.26 $\%$.

Table 2: Descriptive statistics

\begin{tabular}{lrrr}
\hline \multicolumn{1}{c}{ Variables } & N & \multicolumn{1}{c}{ Mean } & Std. D. \\
\hline Earnings management (EM) & 270 & -183.41 & 86.71 \\
Payout ratio (PAOUT) (\%) & 270 & 25.22 & 63.48 \\
Yield ratio (YIELD) (\%) & 270 & 3.08 & 9.20 \\
Institutional ownership & 270 & 30.43 & 24.59 \\
(INOWN)(\%) & & & \\
Block- holder (BKOWN) & 270 & 28.33 & 20.55 \\
Log Firm Size (FSIZE) (BD) & 270 & 5.29 & 0.937 \\
Firm financial leverage (FLEVER) & 270 & 24.45 & 9.26 \\
(\%) & & & \\
Firm performance (ROA) (\%) & 270 & 8.14 & 25.84 \\
\hline
\end{tabular}

Note: 1- For variable definition see Table 1 above;

2- Information on the above variables cover a period of10 years (2004-2013).

\section{4-2 Regression analysis}

Table (3) below provides the findings of the OLS regression model. The model is statistically significant ( $\mathrm{p}$-value is 0.000 ) with F value of 6.842 (see Figure (1) and Figure (2) 
below). The model explains 0.264 of the variations in EM. The coefficient of PAOUT is positive (0.040) and nonsignificant while the coefficient of YIELD is negative (0.017 ) and non-significant. The finding of this study suggests that cash dividends have no impact on EM in the Bahraini capital market. Similar results were reported by Haider et al (2012) and Shah et al (2010). In contrast, other studies (Kasanen et al., 1996; Ahmed et al., 2009 and Liu, 2011) reported cash dividends as one of the motivations to manipulate earnings. Consequently, such finding does not support the research hypothesis (H1).

Regarding the independent variables of firm ownership structure, INOWN and BKOWN, both are negatively associated with EM and are statistically significant. These findings are in line with Cornett et al. (2008), Koh (2003) and Chung et al. (2002) who report a negative association between a high level of institutional ownership and EM. Also, Ben-Naser et al. (2009) and Koh (2003) concluded that institutional ownership plays an active role in reducing EM activities. These results are not in line with what was reported by Al-Fayoumi et al. (2010) who found insignificant associations between institutional and blockholder ownership and EM. Similarly, the results of Siregar and Utama (2008) show that institutional ownership has no significant effect on EM. Based on the above, the finding of the current study supports that institutional and block-holder ownerships can play a vital role in diminishing EM. Accordingly, $\mathrm{H} 2 \mathrm{a}$ and $\mathrm{H} 2 \mathrm{~b}$ can be accepted.

Table 3 shows that the Log of FSIZE is positive of 0.015 but not statistically significant. This result is partially consistent with Chung et al. (2005) who reported positive and statistically significant relation between firm size and EM (at 5\% level). Such results may suggest that large firms engage in EM practice more than small firms. However, the above result is not consistent with Othman and Zeghal (2006) who reported a negative and significant relationship 
with EM. The coefficient of FLEVER is negative of (-0.093) and statistically significant which is consistent with Coulombe and Tondeur (2001) and Naz et al. (2011) who reported a negative association between FLEVER and EM. However, this result does not consistent with Othman and Zeghal (2006) who found FLEVER has no significant association with EM for Canadian firms.

Furthermore, Table 3 shows results of other independent variables, ROA and QAUDT, which are negative and significant. These results are consistent with what was reported by Yoon and Miller (2002). However, they are not consistent with Chung et al. (2005) and McNichols (2000) who reported that EM is significantly positively associated with ROA. QAUDT has a positive coefficient of 0.104 and statistically significant. In the same line, some previous studies such as Krishnan (2003) and Rajgopal et al. (2002) reported similar results which suggest that high-quality auditors might mitigate EM behaviour. The above results suggest that $\mathrm{H} 3, \mathrm{H} 4, \mathrm{H} 5$, and $\mathrm{H} 6$ can be accepted.

Table 3: Regression model of EM and independent variables

\begin{tabular}{|c|c|c|}
\hline & $\begin{array}{c}\text { Standardized } \\
\text { Coefficients }\end{array}$ & $\mathbf{t}$ \\
\hline (Constant) & & 1.537 \\
\hline PAOUT & 0.040 & 1.251 \\
\hline YIELD & -0.017 & -0.521 \\
\hline INOWN & -0.120 & $-4.524 * *$ \\
\hline BKOWN & -0.068 & $-2.548 *$ \\
\hline Log FSIZE & 0.015 & -0.515 \\
\hline FLEVER & -0.093 & $-3.369 * *$ \\
\hline ROA & -0.056 & $-1.984 *$ \\
\hline QAUDT & 0.104 & $3.787 * *$ \\
\hline No. of Observations & 280 & \\
\hline $\mathrm{R}^{2}$ & 0.338 & \\
\hline Adjusted $\mathrm{R}^{2}$ & 0.264 & \\
\hline F value & 6.842 & \\
\hline$P$ value & 0.000 & \\
\hline
\end{tabular}


2. ** significant at the 0.01 level ( 2 -tailed).

3. All variables are defined in Table 1 above.

4. EM is the dependent variable in the above model.

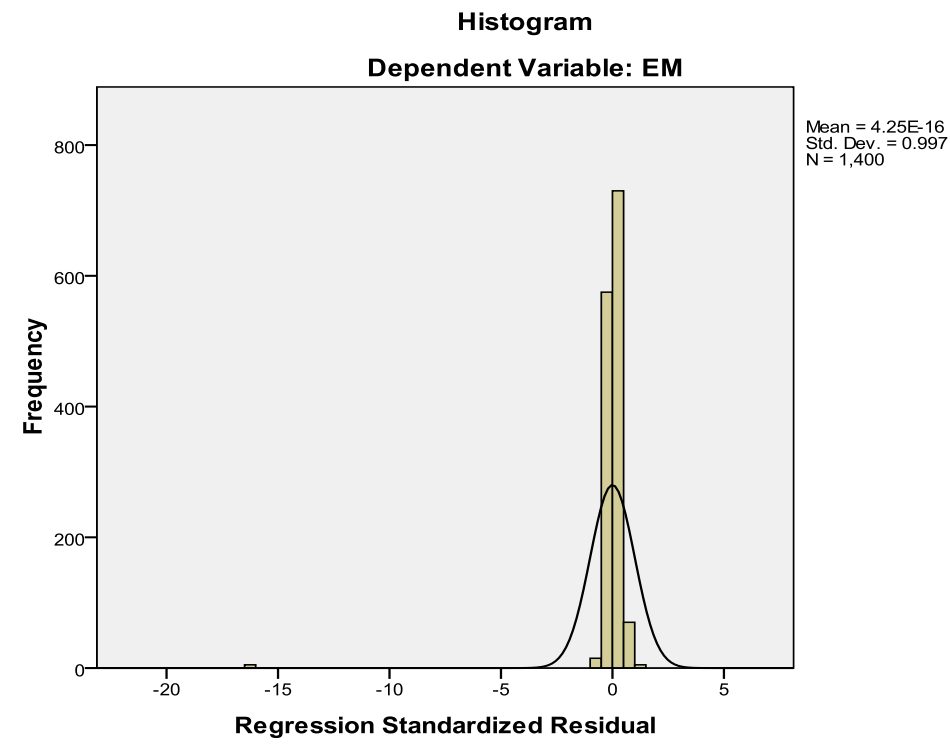

Figure (1) regression standardized residual (Histogram)

To examine the standardized residuals, the study used the histogram (Figure 1) and scatter plots (Figure 2). Figure 1 indicates strong significant relationships between dependent variable (EM) and other independent variables. This confirms the above result presented in Table 3 above. The normal distribution for the data of EM and other independent variables is shown. Figure (2) presents scatter plots which reveals that almost all values of variables employed in the current study are related to each other. 


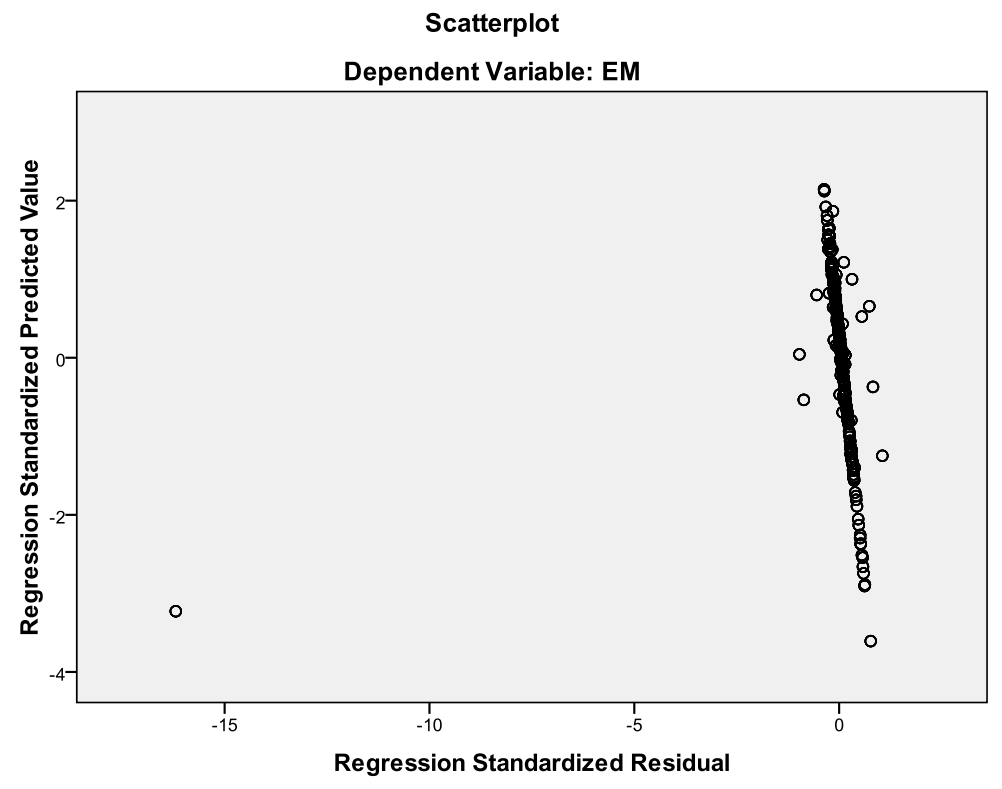

Figure (2) regression standardized residual (scatter plots)

\section{5- CONCLUSIONS, LIMITATIONS AND FUTURE RESEARCH}

The main objective of the current study was to examine the association between cash dividends and firm factors as independent variables and EM measured by Jones Model with a cross sectional approach. The findings showed that cash dividends (PAOUT and YIELD) variables have insignificant impact on EM in Bahraini capital markets. In contrast, firm factors such as (INOWN; BKOWN; Log FSIZE; FLEVER; ROA; and QAUDT) revealed significant associations with EM. Consequently, all hypotheses developed earlier in this study are supported except for $\mathrm{H} 1$, which is rejected.

Similar to a lot of EM studies, the present study has a number of limitations. For example, it depends on Jones model (1991) to estimate discretionary accruals. Such a model includes some of the criticisms. For example, the level of accuracy in classifying accruals into non- 
discretionary and discretionary components is in doubt. In the presence of various industrial activities, developing a new discretionary-accrual model that considers the characteristics of each industry, it is a vital and important area for future research. The study examines 27 Bahraini listed firms with total observations of 270. Extending this sample may need to be considered in other research.

A number of promising trends are still available for future research on EM area of research. Very few studies in GCC area including Bahrain examined some EM aspects and left several factors (such as corporate governance, stock prices, management compensation plans ... etc) which need to be addressed. Furthermore, a number of gaps in EM literature still need to be filled in. For example, what is the magnitude of EM and why firms with similar motivations may have different behaviour in managing their earnings? Finally, under what conditions do capital markets fail to detect EM? Research is needed in the area of managerial behaviour that potentially influences EM as the intersection of insider trading. Suggesting ways to improve the quality of financial reports and then reduce the opportunity of manipulations activities. EM is a promising avenue of research. Future research can use past dividends as an earnings threshold to further examine the debt covenant hypothesis.

\section{ACKNOWLEDGEMENT}

The author is very grateful for the helpful comments given by Dr. Gehan A. Mousa and the Editors of Journal of Accounting Research (Tanta University). Also, Ms Evelenagh Maguire for her work on proof reading the paper.

\section{REFERENCES}

Al-Fayoumi, N., Abuzayed, B. and Alexander, D. (2010). Ownership structure and earnings management in emerging markets: The case of Jordan. International Research Journal of Finance and Economic, 38, 28-47. 
Ahmed, Hafeez, Javid and Yasmin, A. (2009). The determinants of dividend policy in Pakistan. International Research Journal of Finance and Economics, 4, 110-125.

Alves, S. (2012).Ownership structure and earnings management: Evidence from Portugal. Australasian Accounting Business and Finance Journal, 6, 1, 57-74.

Ben-Naser, H, Boubakri, N and Cosset, J (2009). Ownership structure and earnings quality: evidence from newly privatized firms. Available at:

http://www.fma.org/Hamburg/Papers/EQ Privatizedfirm s_Aug09.pdf(Accessed in 30 November 2012).

Brav, A., Graham, J., Harvey, C. and Michaely, R. (2005). Pay-out policy in the $21^{\text {st }}$ century. Journal of Financial Economics, 77, 483-527.

Burgstahler, D. and Dichev. I. (1997). Earnings management to avoid earnings decreases and losses. Journal of Accounting and Economics, 24, 99-126.

Burgstahler, D., and Dichev, I. (1997). Earnings management to avoid earnings decreases and losses. Journal of Accounting and Economics, 24, 99-126.

Caramanis, C. and Lennox, C. (2008). Audit effort and earnings management. Journal of Accounting and Economics, 45, 116-138.

Charoenwong, C. and Jiraporn, P. (2009). Earnings management to exceed thresholds: Evidence from Singapore and Thailand. Journal of Multinational Financial Management, 19, 221-236.

Choi, J., Jean, K. and Park, J. (2004). The role of audit committees in decreasing earnings management: Korean evidence. International Journal of Accounting. Auditing and Performance Evaluation, 1, 1, 37-60.

Chung, R., Firth M. and Kim, J. (2002). Institutional monitoring and opportunistic earnings management. Journal of Corporate Finance, 8, 29-48. 
Chung, R., Firth, M., Kim, J. (2005). Earnings management, surplus free cash flow, and external monitoring, Journal of Business Research, 58, 766- 776.

Coles, J., Hertzel, M. and Kalpathy, S. (2006). Earnings management around employee stock option reissues. Journal of Accounting and Economics,41, 173-200.

Cornett, M., Marcus, A. and Tehraniam, H. (2008). Corporate governance and pay-for-performance: The impact of earnings management. Journal of Financial Economics, 87, 2, 357-375.

Daniel, N., Denis, D. and Naveen, D. (2008). Do firms manage earnings to meet dividend thresholds? Journal of Accounting and Economics, 45, 2-26.

DeAngelo, H., DeAngelo, L. and Stulz, M. (2006). Dividend policy and the earned/contributed capital mix: A test of the life-cycle theory. Journal of Financial Economics, 81, 227-254.

Dechow, P., Sloan, R. \& Sweeney, A. (1996). Causes and consequences of earnings manipulations: An analysis of firms subject to enforcement actions by the SEC. Contemporary Accounting Research, 13, 1, 1-36.

DeFond, M. and Jiambalvo, J. (1994). Debt covenant violation and abnormal accruals. Journal of Accounting and Economics, 117,145-176.

Fama, E. and French, K. (2001). Disappearing dividends: Changing firm characteristics or lower propensity to pay? Journal of Financial Economics, 60, 1, pp. 3-34.

Mousa, G. (2011). An Investigation of Factors Influencing Earnings Management Practices: Evidence from the Egyptian Capital Market. Egyptian Accounting Review, 1, 19- 61.

Graham, J., C. Harvey, and Rajgopal S. (2005). The economic implications of corporate financial reporting. Journal of Accounting and Economics, 40, 3-73.

Haider. J., Ali. A. and Sadiq, T. (2012). Earning management and dividend policy: Empirical evidence 
from Pakistani listed companies, European Journal of Business and Management, 4, 1, 83-90.

Healy, P. and Palepu, K. (1990). Effectiveness of accounting-based dividend covenants. Journal of Accounting and Economics, 12, 97-123.

Healy, P. M. and Wahlen, J. M. (1999). A review of the earnings management literature and its implications for standard setting. Accounting Horizons, 13, 4, 365-383.

Hribar, P. and Collins, D. W. (2002). Errors in estimating accruals: Implications for empirical research. Journal of Accounting Research, 40, 105-134.

Hutchinson, M. and Leung, S. (2007). An Investigation of factors influencing the association between top management ownership and earnings management. Journal of contemporary Accounting \& Economics, 3, 2, 130- 153.

Jensen, M., and Meckling, W. (1976). Theory of the firm: Managerial behavior, agency cost, and capital structure. Journal of Financial Economics, 3, 305-60.

Jones, J. J. (1991). Earnings management during import relief investigations. Journal of Accounting Research, 29, 193-228.

Kasanen, E, Kinnunen, J, and Niskanen, J. (1996). Dividendbased earnings management: Empirical evidence from Finland. Journal of Accounting and Economics, 22, 283312.

Kim, J, Lee, K and Lie, E (2012). Weighing the Evidence on Earnings Management to Meet Dividend Thresholds, Available at: http://tippie.uiowa.edu/accounting/phd/publications/jaew oo-kim\%20-\%20weighing\%20the\%20evidence.pdf (Accessed in 30 June 2013).

Kim J, Chung, R and Firth, M. (2003). Auditor conservatism, asymmetric monitoring and earnings management. Contemporary Accounting Research, 20, 2, pp. 323-359. 
Kinnunen, J, Keloharju, M, Kasanen, E, and Niskanen, J. (2000). Earnings management and expected dividend increases around seasoned share issues: Evidence from Finland. Scandinavian Journal of Management, 16, 209228.

Krishnan, G. (2003). Audit Quality and the Pricing of Discretionary Accruals. Auditing: A Journal of Practice \& Theory, 22, 1, 109-126.

Koh, P, (2003). On the association between institutional ownership and aggressive corporate earnings management in Australia. The British Accounting Review, 35, 105-128.

Lee, B. and Choi, B. (2002). Company size, auditor type, and earnings management. Journal of Forensic Accounting, III, 27-50.

Ling, F. S., Abdull, M.,Shahrin, A. R., and Othman, M. S. (2008). Dividend policy: evidence from public listed companies Malaysia. International Review of Business Research Papers, 4, 4, 208-222.

Lintner, J., (1956). Distribution of incomes of corporations among dividends, retained earnings, and taxes', American Economic Review, 46, 2, 97-113.

Liu, N. (2011).The role of dividend policy in real earnings management, a Dissertation Submitted in Partial Fulfilment of the Requirements for the Degree, the School of Accountancy at Scholar Works, Georgia State University, Available at :

http://scholarworks.gsu.edu/accountancy diss (Accessed in 26 July 2012).

Mousa, G, A (2011) 'An Investigation of Factors Influencing Earnings Management Practices: Evidence from the Egyptian Capital Market', Egyptian AccountingReview, No.1, pp.19- 61.

Moses, D. O. (1987). Income smoothing and incentives: Empirical using accounting changes. The Accounting Review, 2, 259-377. 
McNichols, M.F. (2000). Research design issues in earnings management studies. Journal of Accounting and Public Policy, 19, 313-345.

Naz, I, Bhatti, K, Ghafoor, A. Khan, H, H (2011). Impact of Firm Size and Capital Structure on Earnings Management: Evidence from Pakistan. International Journal of Contemporary Business Studies, 2, 12, 22-31.

Othman, H and Zeghal, D, (2006). A study of earningsmanagement motives in the Anglo-American and EuroContinental accounting models: The Canadian and French cases. The International Journal of Accounting, 41, 406-435.

Rajgopal S, Venkatachalam M, and Jiambalvo J. (2002). Is institutional ownership associated with earnings management and the extent to which stock prices reflect future earnings? Working paper, Stanford University.

Shah. Zulfiqar. S, Hui. Y and Zafar N. (2010). Earning management and dividend policy: An empirical comparison between Pakistani Listed and Chinese listed companies. International Research Journal of Finance and Economics, 35, 23-34.

Siregar, S. V and Utama, S. (2008). Type of earnings management and the effect of ownership structure, firm size, and corporate-governance practices: Evidence from Indonesia. The International Journal of Accounting, 43, $1-27$.

Watts, R.L., and Zimmerman, J.L. (1990). Positive accounting theory: A ten-year perspective. The Accounting Review, 65, 1, 131-156.

Wartfield, T. D.,Wild, J. J., and Wild, K. L. (1995). Managerial ownership, accounting choices and informativeness of earnings. Journal of Accounting and Economics, 20, 61-92.

Yoon, S. S. and Miller, G. A. (2002). Cash from operations and earnings management in Korea, The International Journal of Accounting, 37, 395-412 
Zhong, K., Donald W., and X., Zheng. (2007). The effect of monitoring by outside block holders on earnings management. Quarterly Journal of Business \& Economics, 46, 38-60. 